\begin{tabular}{ll}
\hline \hline INSTITUT ZA RUDARSTVO I METALURGIJU BOR & YU ISSN: 1451-0162 \\
KOMITET ZA PODZEMNU EKSPLOATACIJU MINERALNIH SIROVINA & UDK: 622 \\
\hline \hline
\end{tabular}

UDK: $666.952: 546.54: 669.015: 622.7(045)=861$

Branislav Čađenović, Vesna Marjanović, Vesna Ljubojev", Dragan Milanović*

MOGUĆNOST ISKORIŠĆENJA BAKRENCA IZ TOPIONIČKE ŠLJAKE KOD NJENOG DIREKTNOG IZLIVANJA IZ PEĆI ${ }^{* *}$

\author{
Izvod \\ U ovom radu su prikazana labaratorijska ispitivanja uzoraka šljake iz "Depoa šljake 1" koji se nalazi u \\ industrijskom krugu RTB-a Bor. Ispitivanjem je uočeno izdvanjanje bakrenca sa visokim sadržajem bakra, kao \\ i izdvajanje elementarnog bakra. Zbog boljih ekonomskih efekata treba razmotriti mogućnost fizičke metode \\ koncetracije bakrenca na osnovu njegovih fizičko - hemijskih osobina. \\ Ključne reči: topionička šljaka, bakrenac, bakar, iskorišćenje
}

\section{UVOD}

$\mathrm{U}$ industrijskom krugu RTB Bor u Boru nalaze četiri deponije topioničke šljake. Najznačajnija i najveća deponija šljake iz plamenih peći je „Depo šljake 1”, gde je šljaka odlagana do 1997. godine. Ova deponija šljake može se posmatrati kao tehnogeno ležište mineralnih sirovina, zbog sadržaja korisnih komponenti i mogućnosti njihove valorizacije.

$\mathrm{Na}$ reprezentativnim uzorcima izvršenja su mineraloška, strukturna, fizička i hemijska ispitivanja topioničke šljake.

\section{GEOLOSKE KARAKTERISTIKE TEHNOGENOG LEŽIŠTA "DEPO ŠLJAKE 1"}

Tehnogeno ležište bakra "Depo šljake 1" je izometričnog oblika, čija duža osa ima orijentaciju SZ-JI i dužinu oko $700 \mathrm{~m}$, a kraća osa ima orjentaciju JZ-SI i dužinu oko $200 \mathrm{~m}$. U jugoistočnom delu graniči se sa flotacijskim jalovištem, dok se na severozapadu graniči sa tehnogenim ležištem "Depo šljake 4" na kome se, od 1997. godine deponuje topionička šljaka iz plamenih peći. Severoistočnu granicu ležišta čini jalovište površinskog kopa, a jugozapadnu industrijska postrojenja TIRa (Fabrika sumporne kiseline, topionička postrojenja i termoelektrana), te industrijska putna i železnička infrastruktura.

Geološke karakteristike tehnogenog ležišta bakra "Depo šljake 1" uslovljene su, pre svega, neposrednom podlogom na kojoj su deponovane, kao i načinom obrazovarnja deponije. Podloga deponije najvećim delom je tehnogeni materijal tj. stenska otkrivka sa površinskog kopa,

\footnotetext{
*Institut za rudarstvo i metalurgiju Bor

** Ovaj rad je proistekao kao rezultat projekta evidencioni broj TR 33023 „Razvoj tehnologija flotacijske prerade ruda bakra i plemenitih metala radi postizanja boljih tehnoločkih rezultata" finansiranog od strane Ministarstva prosvete i nauke Republike Srbije.
} 
prethodno deponovaniu u koritu Borske reke, dok su samo malim delom neposredno ispod šljake geogene tvorevine (borski konglomerati, vulkanoklastične stene i aluvion). Deponija je stvarana sukcesivnim izlivanjem užarenog rastopa šljake, pa je u tom pogledu slična izlivima lave.[1]

\section{ŠLJAKA IZ METALURŠKOG PROCESA TOPLJENJA ŠARŽE U TOPIONICI U BORU}

Kod svih pirometalurških procesa dobijanja metala (bakra), pored osnovnog produkta (metalnog rastopa), obrazuje se i druga tečna faza (šljaka), koja sadrži nemetalične uključke i novoobrazovane okside, i predstavlja balast prilikom dobijanja čistog metala. Da bi proces dobijanja metala tekao po tehnološkom zahtevu, neophodno je da šljaka ispunjava sledeće uslove:

- šljake moraju imati dobru tečljivost, $\mathrm{i}$

- da se dobro odvajaju od metala (bakrenca) i da dobro rastvaraju razne elemente koji štetno utiču na osobine metala, koji se u procesima dobijaju.

Šljake predstavljaju složene sisteme od većeg broja komponenata, a najčešće su to rastopi različitih oksida sa vrlo visokim temperaturama topljenja.

Sastav šljake veoma utiče na tok samog metalurškog procesa, kao i na kvalitet konačnog proizvoda, pa se zato značaju šljake u metalurgiji sve više posvećuje posebna pažnja.

Za objašnjenje formiranja i strukture metalurških šljaka koristi se molekularna teorija i jonska teorija obrazovanja šljake.
Osnovne komponente šljake prilikom topljenja bakarnog koncentrata $\mathrm{su} \mathrm{SiO}_{2}$, $\mathrm{FeO}, \mathrm{Fe}_{2} \mathrm{O}_{3}$ i $\mathrm{MgO}$. Pored navedenih komponenti šljaka često sadrži $\mathrm{Fe}_{3} \mathrm{O}_{4}$, $\mathrm{Al}_{2} \mathrm{O}_{3}, \quad \mathrm{Cu}_{2} \mathrm{~S}$, i skoro redovno sitne kapljice mehanički zahvaćenog bakrenca.

Jedinjenje $\mathrm{FeO} u$ šljaci se najčešće nalazi u obliku fajalita $(\mathrm{FeO})_{2} \cdot \mathrm{SiO}_{2}$, ali u fajalitu može biti rastvoren i višak gvožđe-oksida, kao što je slučaj u baznim šljakama.

Fajalit $\left(\mathrm{Fe}_{2} \mathrm{SiO}_{4}\right)$ pripada grupi olivina koji kristališu rombično $\mathrm{u}$ obliku kratkostubičastih kristala ili se pojavljuju u zrnastim agregatima. Najčešće imaju karakterističnu maslinastozelenu boju po kojoj su i dobili ime, ali mogu biti i različito obojeni od bele, svetlozelene, preko maslinaste i tamnozelene, do crne. Staklaste su sjajnosti ili masne na prelomima. Gotovo su bez cepljivosti, tvrdine 6,5-7.[4]

Šljake plamene peći prema svom hemijskom sastavu i stvarnoj rastvorljivosti bakrenca u njima, u stanju ravnoteže, trebalo bi da sadrže 0,15 do $0,25 \%$ bakra.

To se međutim ne postiže u prvenstveno zbog značajnog prisustva mehanički uključenog bakrenca u šljakama, kao i zbog hemijski vezanog bakra u obliku oksida u slučaju kada se topi prženac.

\section{LABARATORIJSKA ISPITIVANJA}

$\mathrm{Na}$ pet reprezativnih uzoraka šljake izvršene su minerološke i labaratorijske analize. Hemijski sastav uzoraka šljake dat je u tabeli 1., a hemijski sastav reprezan-tativnog uzorka šljake dat je u tabeli 2 . 
Tabela 1. Hemijski sastav rovne šljake plamenih peći

\begin{tabular}{|c|c|c|c|c|c|c|}
\hline Elementi, \% & $\check{\text { S. }} \mathbf{1 / 1}$ & $\check{S}-1 / 2$ & $\check{S}-\mathbf{1} / 3$ & $\breve{S}-1 / 4$ & $\breve{S}-\mathbf{1} / \mathbf{5}$ & Prosečni sadržaj \\
\hline $\mathbf{C} \mathbf{u}_{\text {uk. }}$ & 0,560 & 0,610 & 0,870 & 0,850 & 0,980 & 0,747 \\
\hline $\mathrm{Cu}$ oks. & 0,166 & 0,352 & 0,130 & 0,223 & 0,178 & 0,233 \\
\hline $\mathbf{C u}$ sulf. & 0,394 & 0,258 & 0,740 & 0,617 & 0,800 & 0,511 \\
\hline $\mathbf{S}$ & 0,610 & 0,920 & 0,720 & 0,790 & 1,390 & 0,892 \\
\hline $\mathrm{Fe}$ & 37,70 & 34,98 & 37,14 & 37,05 & 37,89 & 36,62 \\
\hline $\mathrm{Fe}_{2} \mathrm{O}_{3}$ & 11,98 & 9,300 & 14,01 & 15,04 & 16,13 & 12,63 \\
\hline $\mathrm{Fe}_{3} \mathrm{O}_{4}$ & 8,760 & 8,540 & 9,680 & 9,38 & 9,290 & 9,030 \\
\hline $\mathrm{SiO}_{2}$ & 34,03 & 34,52 & 34,66 & 33,45 & 33,04 & 34,04 \\
\hline $\mathbf{A l}_{2} \mathbf{O}_{3}$ & 4,670 & 6,080 & 5,010 & 3,230 & 5,330 & 5,066 \\
\hline Mo & 0,160 & 0,140 & & 0,042 & 0,020 & 0,100 \\
\hline $\mathbf{A g}$ & 3,000 & 4,900 & & 3,500 & 3,500 & 3,725 \\
\hline $\mathbf{A u}$ & $<0,500$ & 0,800 & & 0,500 & 0,300 & 0,525 \\
\hline
\end{tabular}

Tabela 2. Hemijski sastav

reprezentativnog uzorka šljake

\begin{tabular}{|c|c|c|}
\hline $\begin{array}{c}\text { Elementi, } \\
\text { \% }\end{array}$ & Šljaka & $\begin{array}{c}\text { Analitička } \\
\text { metoda }\end{array}$ \\
\hline $\mathbf{C u}$ & 0,33 & $\mathrm{AAS}$ \\
\hline $\mathbf{S}$ & 0,20 & $\mathrm{G}$ \\
\hline $\mathbf{F e}$ & 27,92 & $\mathrm{~V}$ \\
\hline $\mathbf{S i O}$ & 46,72 & $\mathrm{G}$ \\
\hline $\mathbf{C a O}$ & 19,60 & $\mathrm{~V}$ \\
\hline $\mathbf{A l}_{\mathbf{2}} \mathbf{O}_{\mathbf{3}}$ & 4,52 & $\mathrm{ICP}-\mathrm{AES}$ \\
\hline $\mathbf{F e}_{\mathbf{3}} \mathbf{O}_{\mathbf{4}}$ & 3,41 & $\mathrm{~A}-\mathrm{Fe}_{3} \mathrm{O}_{4}$ \\
\hline
\end{tabular}

AAS-atomska apsorpciona spektrofotometrija, $G$ - gravimetrija,

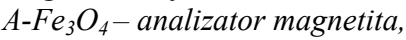

$V$-volumetrija,

ICP-AES - atomska emisiona spektrometrija sa induktivno kuplovanom plazmom.

\section{MINERALOŠKA ISPITIVANJA}

Mineraloška determinacija topioničke šljake iz plamenih peći urađena je sa najvećeg i najznačajnijeg depoa "Depo šljake 1". Šljaku tehnogenog ležišta bakra "Depo šljake 1" karakteriše heterogenost u pogledu fizičkih, mineraloških i hemijskih osobina. To je posledica raznovrsnosti ruda, koncentrata i topitelja koji su korišćeni u procesu topljenja, kao i tehnologije koje su primenjivane $\mathrm{u}$ relativno dugom period (do
1943. do 1997. godine). Od reprezentativnog uzorka topioničke šljake pod oznakom Š - 1, za kvalitativno-kvantitativnu minera-lošku analizu uzeta su pet uzorka za izradu rudnih

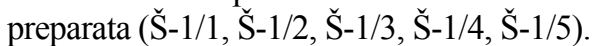

$\mathrm{Na}$ uzetim uzorcima izvršena je determinacija mineralnog sastava i određivanje strukturno-teksturnih karakteristika minerala.

Kvalitativna mineraloška analiza rađena je pod polarizacionim mikroskopom za odbijenu svetlost u vazduhu, sa indentifikacijom rudnih i nerudnih minerala. Kvantitativna mineraloška analiza rađena je metodom paralelnih profila, sa rastojanjem od $1 \mathrm{~mm}$. Rastojanje između ispitivanih polja i profila pomerana su ručno. Determinacja uzoraka šljake rađena je mikroskopom za propuštenu i odbijenu svetlost, marke AXIOSKOP 40, sa uređajem za mikrofotografiju.

$\mathrm{Na}$ osnovu kvalitativnih mineraloških analiza utvrđen je sledeći mineralni sastav šljake: čvrsti sulfidni rastop $(\mathrm{Cu}-\mathrm{Fe})$, halkozin, pirit, bakar, halkopirit, bornit, magnetit i minerali jalovine (nemetalidni minerali), predstavljeni su staklom sa pojavom razllčitih eutekličkih dendrita (fajalit i dr.) koji nisu posebno određivani. 


\section{Makroskopski opis uzorka: $\breve{S}-1 / 1$}

Uzorak je tamnosive boje, čeličnog sjaja. Na nekim mestima javlja se irizirajuća zelenoplava nijansa zbog dužeg stajanja šljake na vazduhu. Na površini uzorka vidljive su sferične šupljine, što ukazuje da je uzorak proizvod toljenja rude-šljake, slika 1.
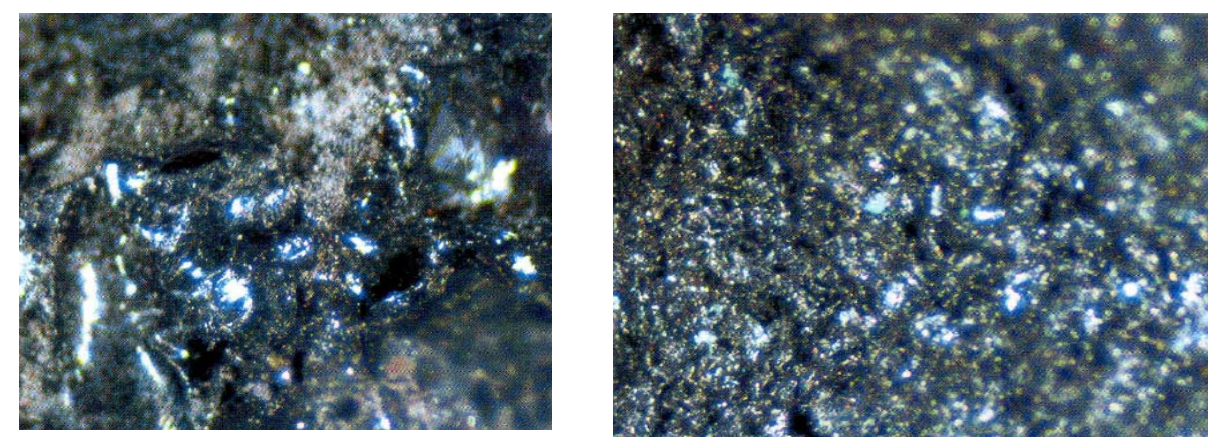

SI. 1. Makroskopski izgled šljake, binokular, uvećanje 50 puta

\section{Mikroskopski opis uzorka: $\breve{S}-1 / 1$}

Kvalitativnom minerološkom analizom utvrđen je sledeći mineralni sastav: fajalit, ferit, pirit, halkozin, bornit, čvrsti sulfidni rastvor (bakrenac) i samorodni (metalni) bakar.

Osnova šljake je izrađena od fajlita i ferita u koju su uprskane sitne čestice pirita, halkopirita, halkozina, bornita, bakrenca i samorodnog (metalnog) bakra. Fajaliti su zastupljeni u vidu pritkastik kristalića. Feriti su zastiljeni u vidu skeletnih kristala

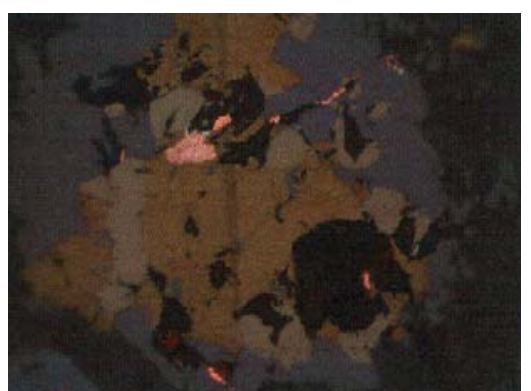

SI. 2. Sraslac halkopirita, pirit i bakrenac sa izdvajanjem elementarnog bakra, objektiv 50x, II Nikoli (dendriti). Fajaliti i feriti su proizvod topljenja rude - šljake. Pirit je najzastupljeniji od svih sulfidnih minerala, u vidu zrna sferičnih i nepravilnih formi. Pirit je uglavnom srastao sa jalovinom. Od minerala bakra javljaju se halkopirit, halkozin i bornit. Samorodni bakar se retko uočava u vidu sitnih žilica i zrnastih formi. Mikrofotografije uzoraka šljake prikazane su na slikama 2, 3 i 4 .

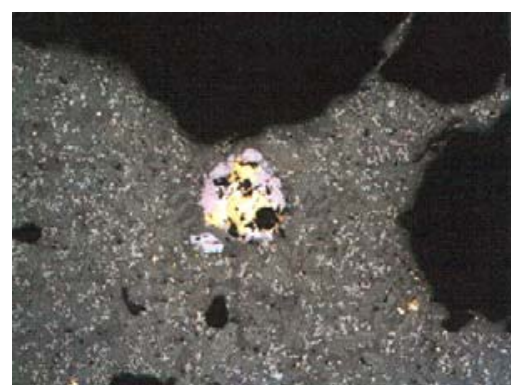

SI. 3. Sraslac halkopirita, pirit i bornita $u$ fajalitskoj osnovi, objektiv 10x, II Nikoli 


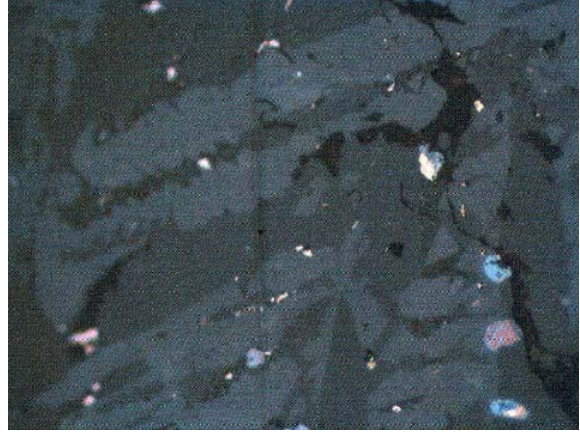

Sl. 4. Sraslac pirita i halkozina, halkozin $i$ bakrenac, objektiv 50X, II Nikoli

\section{TEHNIČKI OPIS}

\section{PROCESA GRANULACIJE U}

\section{LABORATORIJSKIM USLOVIMA}

Pod pojmom granulacije se podrazumeva naglo hlađenje tečne šljake pod pritiskom hladne vode $\mathrm{i}$ dobijanje šljake $\mathrm{u}$ vidu nepravilnih granula. Kvalitet granula zavisi od hemijskog sastava šljake, temperature šljake pre izlivanja, brzine izlivanja šljake, pritiska i količine rashladne vode.

Za laboratorijske uslove korišćena je šljaka koja je uzeta sa deponije, u komadastom obliku, različitih veličina.

Pošto takva prikupljena šljaka, koja

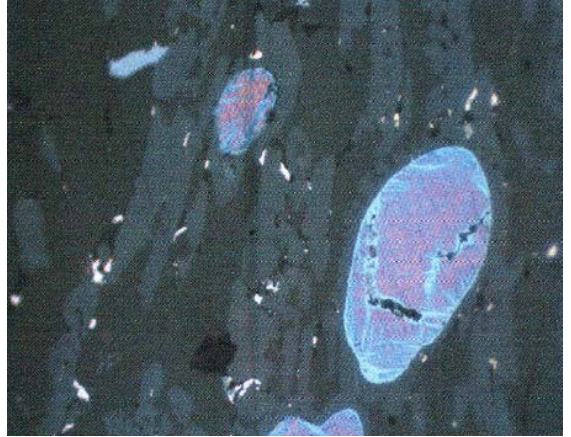

SI. 5. Bakrenac u fajalitskoj osnovi,objektiv 50X, II Nikoli

Tabela 3. Hemijski sastav uzorka

\begin{tabular}{|c|c|c|c|c|c|c|c|c|}
\hline $\begin{array}{c}\text { Jedinjenja- } \\
\text { hemijski elementi }\end{array}$ & $\mathbf{C u}$ & $\mathbf{F e}_{\mathbf{3}} \mathbf{O}_{\mathbf{4}}$ & $\mathbf{C a O}$ & $\mathbf{S}$ & $\mathbf{F e}$ & $\mathbf{F e O}$ & $\mathbf{S i O}_{\mathbf{2}}$ & $\mathbf{A l}_{\mathbf{2}} \mathbf{O}_{\mathbf{3}}$ \\
\hline Sadržaj, \% & 0,68 & 1,754 & 17,26 & 1,07 & 25,69 & 26,75 & 43,76 & 3,89 \\
\hline
\end{tabular}

Granulacija šljake je rađena $u$ laboratorijskim uslovima, a za njeno izvođenje korišćen je specijalni uređaj za pravljenje granulata. Prethodno osušena i analizirana šljaka je podvrgnuta topljenju $\mathrm{u}$ indukcionoj peći za topljenje, snage 100 $\mathrm{kWh}, \mathrm{u}$ loncu zapremine $\mathrm{V}=10 \quad$, proizvođača ELING - Loznica. Prilikom eksperimenta istopljeno je $25 \mathrm{~kg}$ šljake (hemijskog sastava prikazanog u tabeli 1), temperatura pri kojoj je šljaka izlivena je je bila izložena atmosferilijumu, sadrži i fizičku vlagu, pre nego što se otpočne sa njenim topljenjem neophodno je njeno sušenje. Dopremljena šljaka je podvrgnuta prirodnom sušenju, odnosno, rasprostrta je na veću površinu, kako bi eliminisali fizičku vlagu. Po završetku prirodnog sušenja uzima se više uzoraka sa različitih mesta i formira kompozitni uzorak, koji se upućuje na analizu. Hemijski sastav uzorka je prikazan u tabeli 3 . bila $\mathrm{t}=1250^{\circ} \mathrm{C}$. Merenje temperature šljake obavljeno je potapajućim pirometrom.

\section{Opis granulatora}

Konstruisani specijalni granulator je mobilan i omogućava, da se šljaka naglo hladi mlaznicama, koje se nalaze na čeonoj prednjoj strani rezervoara, odmah iza valjka granulatora, kome je jedan deo potopljen u rashladnu vodu. Ispod valjka je prihvatni koš sa perforiranim dnom, 
koji prihvata nastale granule i koji se nakon izlivanja celokupne količine šljake iz peći vadi uz pomoć dizalice i nakon ceđenja, odlaže u korpu za granulisanu šljaku.
U tako konstruisan granulator granulisano je $25 \mathrm{~kg}$ šljake. Sastav granulisane šljake dat je u tabeli 4 .

Tabela 4. Hemijski sastav granulisane šljake

\begin{tabular}{|c|c|c|c|c|c|c|c|}
\hline $\begin{array}{c}\text { Jedinjenja- hemijski } \\
\text { elementi }\end{array}$ & $\mathbf{C u}$ & $\mathbf{S}$ & $\mathbf{F e}$ & $\mathbf{S i O}_{\mathbf{2}}$ & $\mathbf{C a O}$ & $\mathbf{A l}_{\mathbf{2}} \mathbf{O}_{\mathbf{3}}$ & $\mathbf{F e}_{\mathbf{3}} \mathbf{O}_{\mathbf{4}}$ \\
\hline Sadržaj, \% & 0,33 & 0,20 & 27,92 & 46,72 & 19,60 & 4,52 & 3,41 \\
\hline
\end{tabular}

Razlika u hemiskom sastavu, pre i posle granulisanja šljake, objašnjava se izdvajanjem posebne faze (bakrenca- $\mathrm{Cu}_{2} \mathrm{~S} \mathrm{FeS}$ ) koja je bila zarobljena u komadima šljake.

Posle izvršene granulacije ručnim odabiranjem izdvojena je mala količina bakrenca, koja je data na hemijsku analizu. Rezultati hemijske analize bakrenca dati su u tabeli 5 .

Tabela 5. Hemijski sastav bakrenca iz granulisane šljake

\begin{tabular}{|c|c|c|}
\hline $\begin{array}{c}\text { Elementi, } \\
\text { \% }\end{array}$ & Šljaka & $\begin{array}{c}\text { Analitička } \\
\text { metoda }\end{array}$ \\
\hline $\mathbf{C u}$ & 17,04 & $\mathrm{EG}$ \\
\hline $\mathbf{F e}$ & 36,38 & $\mathrm{~V}$ \\
\hline $\mathbf{S}$ & 15,13 & $\mathrm{~S}$ \\
\hline $\mathbf{C a O}$ & 7,40 & $\mathrm{AAS}$ \\
\hline $\mathbf{F e O}$ & 44,02 & $\mathrm{R}$ \\
\hline $\mathbf{F e}_{\mathbf{3}} \mathbf{O}_{\mathbf{4}}$ & 6,53 & $\mathrm{~A}-\mathrm{Fe}_{3} \mathrm{O}_{4}$ \\
\hline $\mathbf{S i O}_{\mathbf{2}}$ & 17,00 & $\mathrm{G}$ \\
\hline $\mathbf{A l}_{\mathbf{2}} \mathbf{O}_{\mathbf{3}}$ & 1,63 & $\mathrm{AAS}$ \\
\hline
\end{tabular}

AAS - atomska apsorpciona spektrofotometrija, $G$ - gravimetrija,

A-Fe3O4 - analizator magnetita,

$V$-volimetrija, $E G$ - ,

$S$-Spaljivanje,

$R$-Računski

\section{ZAKLJUČAK}

$\mathrm{Na}$ osnovu hemijskih i mineroloških analiza može se zaključiti da se prilikom granulisanja šljake izdvajuju dve faze:

- siromašnija na bakru (granulisana šljaka) sa $0,33 \% \mathrm{Cu}$, tabela 4 ,

- bogatija na bakru (bakrenac) sa $17,04 \% \mathrm{Cu}$, tabela 5 .
U daljem našem radu razmotrićemo mogućnost dobijanja bakrenca primenom fizičih metoda koncetracije. Veliki sadržaj bakra u bakrencu daje mogućnost povećanja ekonomske dobiti zbog povoljne cene bakra na našem i svetskom tržištu. Na osnovu fizičko - hemijskih karakteristika bakrenca treba razmotriti mogućnost primene fizičih metoda koncentracije u cilju njegovog izdvajanja iz fajalitske osnove, kao i mogućnost eksperimentalne proizvodnje zbog unapređenja tehnoloških rezultata.

\section{LITERATURA}

[1] D. Kržanović, R. Rajković, V. Marinković, Geološke karakteristike, modeliranje i tehničko rešenje otkopavanja tehnogenog ležišta bakra „Depo šljake 1“ u Boru, Rudarski radovi 1(2009), str. 7-17

[2] S. Magdalinović, D. Milanović, B. Čađenović, V. Marjanović: Tehnološki postupak granuliranja šljake radi sniženja krupnoće na ulazu u flotaciju, Rudarski radovi, 3(2011), str. 101-111.

[3] B. Čađenović, B. Drobnjaković, D. Milanović, S. Magdalinović, Novo laboratorijsko postrojenje za granuliranje izmenjenim tehnološkim postupkom izlivanja topioničke šljake, Rudarski radovi, 4(2011), str. 93-99.

[4] www.scribd.com/doc/39205125/ Minerali-i-Magmatske-Stene 


$\begin{array}{ll}\text { MINING AND METALLURGY INSTITUTE BOR } & \text { YU ISSN: 1451-0162 } \\ \text { COMMITTEE OF UNDERGROUND EXPLOITATION OF THE MINERAL DEPOSITS } & \text { UDK: } 622\end{array}$

UDK: 666.952:546.54:669.015:622.7(045) $=20$

Branislav Čađenović, Vesna Marjanović, Vesna Ljubojev", Dragan Milanović*

\title{
POSSIBILITIES OF USE THE COPPER MATTE FROM SMELTER SLAG IN ITS DIRECT BAKRENCA OF SMELTING SLAG IN ITS DIRECT DISCHARGE FROM FURNACE
}

\begin{abstract}
This paper presents the laboratory testing of slag samples from the "Slag Depot 1", located in the industrial site of RTB Bor. Testing revealed a separation of copper matte with high copper content, as well as the separation of elemental copper. Due to the better economic effects, should be considered a possibility of physical concentration method of copper matte has to be considered, based on its physical and chemical properties.
\end{abstract}

Keywords: smelter slag, copper matte, copper, recovery

\section{INTRODUCTION}

There are four dumps of smelter slag in the industrial site of RTB Bor. The most important and the biggest slag dump from reverberatory furnaces is the "Slag Depot 1", where the slag was delayed until 1997. This slag dump can be considered as a technogenic deposit of mineral resources due to the content of useful components and capabilities of their recovery.

Mineralogical, structural, physical and chemical testing of smelter slag were done on representative samples.

\section{GEOLOGICAL CHARACTERISTICS OF THE TECHNOGENIC DEPOSIT} “SLAG DEPOT 1"

Technogenic copper deposit "Slag Depot 1" has an isometric form with NW-SE orientation of longer axis and length of approx. $700 \mathrm{~m}$, and NE-SW orientation of shorter axis and length of approx. $200 \mathrm{~m}$. In the southeastern part, it borders the flotation tailing dump, while in the northwest it borders the technogenic deposit "Slag Depot 4" where, since 1997, the smelter slag is delayed from the reverberatory furnaces. Northeastern border of the deposit includes the waste dump of the open pit, southwestern border includes the industrial facilities of TIR (Sulphuric Acid Plant, smelter facilities and power plants), and industrial road and rail infrastructure.

Geological characteristics of the technogenic copper deposit "Slag Depot 1" are conditioned, first of all, by the immediate surface on which they are deposited and a

\footnotetext{
* Mining and Metallurgy Institute Bor

** This work is the result of the Project No. TR 33023 "Development of Technologies for Flotation Processing the Copper Ore and Precious Metals to Realize Better Technological Results", funded byt the Ministry of Education and Science of the Republic of Serbia
} 
method of landfill formation. Surface of the landfill was mostly technogenic material, i.e. waste rock from the open pit, previously delayed in the bed of the Bor River, while the geogenic formations are only a small portion just below the slag (the Bor conglomerates, volcanic-clastic rocks and alluvium). The landfill was created by successive discharging the red-hot molten slag, and in this respect similar to the outpourings of lava. [1]

\section{SLAG FROM THE \\ METALLURGICAL PROCESS OF CHARGE SMELTING IN THE SMELTER IN BOR}

In all pyrometallurgical processes of metal obtaining (copper), in addition to the basic product (molten metal), the second liquid phase (slag) is formed, which contains non-metallic inclusions and newly formed oxides, and presents a ballast in obtaining the pure metal. To make the process of metal obtaining according to the technological requirement, it is necessary that slag meets the following requirements:

- slag must have good flowability, and

- slag must be well separated from the metal (copper matter) and dissolve well various elements that adversely affect the properties of metals, obtained in the processes.

Slag is complex systems of a number of components; most often those are molten of various oxides with high melting temperatures.

Slag composition greatly affects the flow of metallurgical process and quality of the final product, and therefore more attention is paid to the importance of metallurgical slag.
The molecular theory and ion theory of slag formation are used for an explanation of formation and structure of metallurgical slag.

The basic components of slag during smelting of copper concentrates are: $\mathrm{SiO}_{2}$, $\mathrm{FeO}, \mathrm{Fe}_{2} \mathrm{O}_{3}$ and $\mathrm{MgO}$. In addition to these components, the slag often contains $\mathrm{Fe}_{3} \mathrm{O}_{4}$, $\mathrm{Al}_{2} \mathrm{O}_{3}, \mathrm{Cu}_{2} \mathrm{~S}$, and almost always small drops mechanically affected copper matte.

Compound $\mathrm{FeO}$ in slag is commonly found in the form of fayalite $(\mathrm{FeO})_{2} \cdot \mathrm{SiO}_{2}$, but the excess iron oxide can be dissolved in fayalite, as it is the case in basic slag.

Fayalite $\left(\mathrm{Fe}_{2} \mathrm{SiO}_{4}\right)$ belongs to a group of olivine that is crystallized into rhombicshaped crystals or appears in granular aggregates. Usually they have a distinctive olive drab color on which they were named, but they may be differently colored from white, light green, through olive and dark green to black. They have glassy brightness or greasy on fractures. They are almost without tearing, hardness from 6.5 to 7 . [4]

Slag of reverberatory furnace, according to its chemical composition and actual solubility of copper matter in it, in equilibrium, should contain 0.15 to $0.25 \%$ copper.

It is however not achieved, primarily due to the presence of mechanically included copper matte in the slag, as well as chemically bounded copper in the form of copper oxide when the calcine is melted.

\section{LABORATORY TESTING}

Mineralogical and laboratory analyses were carried out on five representative samples. Chemical composition of slag sample is given in Table 1, and chemical composition of representative slag sample is given in Table 2 . 
Table 1. Chemical composition of raw slag from reverberatory furnace

\begin{tabular}{|c|c|c|c|c|c|c|}
\hline Elements, \% & $\mathbf{S - 1 / 1}$ & $\mathbf{S - 1 / 2}$ & $\mathbf{S - 1 / 3}$ & $\mathbf{S - 1 / 4}$ & $\mathbf{S - 1 / 5}$ & Average content \\
\hline $\mathbf{C} \mathbf{u}_{\text {total }}$ & 0.560 & 0.610 & 0.870 & 0.850 & 0.980 & 0.747 \\
\hline $\mathbf{C} \mathbf{u}_{\text {oxid. }}$ & 0.166 & 0.352 & 0.130 & 0.223 & 0.178 & 0.233 \\
\hline $\mathbf{C u _ { \text { sulf. } }}$ & 0.394 & 0.258 & 0.740 & 0.617 & 0.800 & 0.511 \\
\hline $\mathbf{S}$ & 0.610 & 0.920 & 0.720 & 0.790 & 1.390 & 0.892 \\
\hline $\mathbf{F e}$ & 37.70 & 34.98 & 37.14 & 37.05 & 37.89 & 36.62 \\
\hline $\mathbf{F e}_{\mathbf{2}} \mathbf{O}_{\mathbf{3}}$ & 11.98 & 9.300 & 14.01 & 15.04 & 16.13 & 12.63 \\
\hline $\mathbf{F e}_{\mathbf{3}} \mathbf{O}_{\mathbf{4}}$ & 8.760 & 8.540 & 9.680 & 9.38 & 9.290 & 9.030 \\
\hline $\mathbf{S i O}_{\mathbf{2}}$ & 34.03 & 34.52 & 34.66 & 33.45 & 33.04 & 34.04 \\
\hline $\mathbf{A l}_{\mathbf{2}} \mathbf{O}_{3}$ & 4.670 & 6.080 & 5.010 & 3.230 & 5.330 & 5.066 \\
\hline $\mathbf{M o}$ & 0.160 & 0.140 & & 0.042 & 0.020 & 0.100 \\
\hline $\mathbf{A g}$ & 3.000 & 4.900 & & 3.500 & 3.500 & 3.725 \\
\hline $\mathbf{A u}$ & $<0.500$ & 0.800 & & 0.500 & 0.300 & 0.525 \\
\hline
\end{tabular}

Table 2. Chemical composition of a representative slag sample

\begin{tabular}{|c|c|c|}
\hline $\begin{array}{c}\text { Elements, } \\
\text { \% }\end{array}$ & Slag & $\begin{array}{c}\text { Analytical } \\
\text { method }\end{array}$ \\
\hline $\mathbf{C u}$ & 0.33 & $\mathrm{AAS}$ \\
\hline $\mathbf{S}$ & 0.20 & $\mathrm{G}$ \\
\hline $\mathbf{F e}$ & 27.92 & $\mathrm{~V}$ \\
\hline $\mathbf{S i O} \mathbf{O}_{\mathbf{2}}$ & 46.72 & $\mathrm{G}$ \\
\hline $\mathbf{C a O}$ & 19.60 & $\mathrm{~V}$ \\
\hline $\mathbf{A l}_{\mathbf{2}} \mathbf{O}_{3}$ & 4.52 & $\mathrm{ICP}-\mathrm{AES}$ \\
\hline $\mathbf{F e}_{\mathbf{3}} \mathbf{O}_{\mathbf{4}}$ & 3.41 & $\mathrm{~A}-\mathrm{Fe}_{3} \mathrm{O}_{4}$ \\
\hline
\end{tabular}

$A A S$ - atomic absorption spectrophotometry, $G$ - gravimetry,

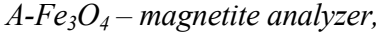

$V$-volumetry,

ICP-AES - atomic emission spectrometry with inductively coupled plasma.

\section{MINERALOGICAL TESTING}

Mineralogical determination of smelter slag from reverberatory furnaces was carried out from the biggest and most important depot the "Slag Depot 1." Slag from copper technogenic deposit the "Slag Depot 1" is characterized by heterogeneity in terms of physical, mineralogical and chemical properties. This is a consequence of various ores, concentrates and flux, used in the smelting process, and the applied technologies in a relatively long period (from 1943 to 1997).
From a representative sample of smelter slag, marked $\check{S}-1$, for the qualitativequantitative mineralogical analysis, five samples were taken for development of min-

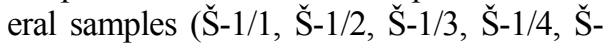
$1 / 5)$.

Determination of mineral composition and structural-textural properties of minerals was carried out on taken samples.

Qualitative mineralogical analysis was carried out under the polarizing microscope for reflected light in the air, with identification of ore and non-ore minerals. Quantitative mineralogical analysis was carried out using the method of parallel profiles with distance of $1 \mathrm{~mm}$. Distances between the investigated fields and sections were relocated manually. Determination the slag samples was carried out using a microscope for missed and reflected light, brand AXIOSKOP 40, with device for photomicrography.

Based on the qualitative mineralogical analysis, the following mineral composition of slag was identified: solid sulphide melt $(\mathrm{Cu}-\mathrm{Fe})$, chalcocite, pyrite, copper, chalcopyrite, bornite, magnetite and waste minerals (non-metal minerals); they were presented by a glass with appearance of various eutectic dendrites (fayalite and others) not specifically determined. 
Macroscopic description of sample: Š-1/1

Sample is a dark gray with steel shine. In some places there is irritating green-blue shade due to longer standing of slag on the

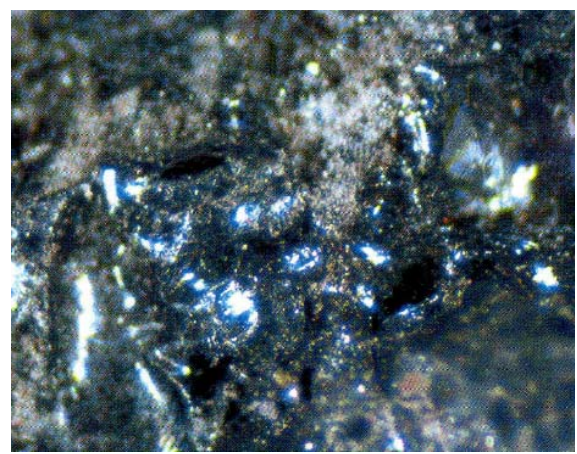

air. On the sample surface, there are visible spherical cavities, indicating that the sample is a product of ore-slag smelting, Figure 1.

Fig. 1. Macroscopic view of slag, binocular, magnification 50 times

\section{Microscopic description of sample: $\check{S}-1 / 1$}

Qualitative mineralogical analysis has identified the following mineral composition: fayalite, ferrite, pyrite, chalcocite, bornite, solid sulfide solution (copper matte) and native (metallic) copper.

The base of slag is made of fayalite and ferrite in which the tiny particles of pyrite, chalcopyrite, chalcocite, bornita, copper matte and native (metallic) copper are disseminated. Fayalites are represented in the form of rodding crystals. Ferrites are represented in the form of skeletal

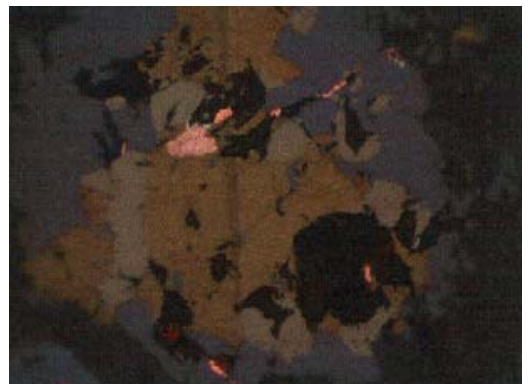

Fig. 2. Intergrowth of chalcopyrite, pyrite and copper matte with separation of elemental copper, lens 50X, II Nikoli

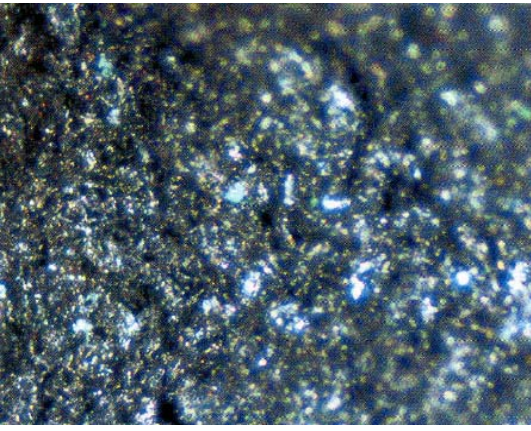

crystals (dendrites). Fayalite and ferrites are the product of smelting - slag. Pyrite is the most present of all sulphide minerals in the form of spherical beads and irregular forms. Pyrite is generally intergrown to the waste. Copper minerals occur as chalcopyrite, chalcocite and bornite. Native copper is rarely observed in the form of small veins and granular forms. Microphotographies of slag samples are shown in Figures 2, 3 and 4.

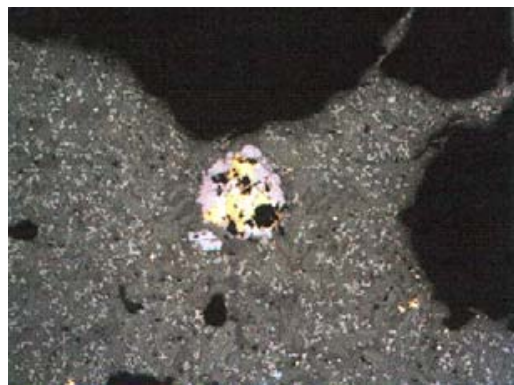

Fig. 3. Intergrowth of chalcopyrite, pyrite and bornite in fayalitic basis, lens 10X, II Nikoli 


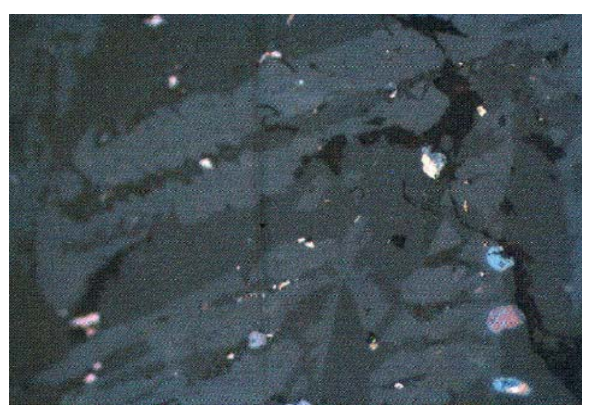

Fig. 4. Intergrowth of pyrite, chalcocite and copper matte, lens 50X, II Nikoli

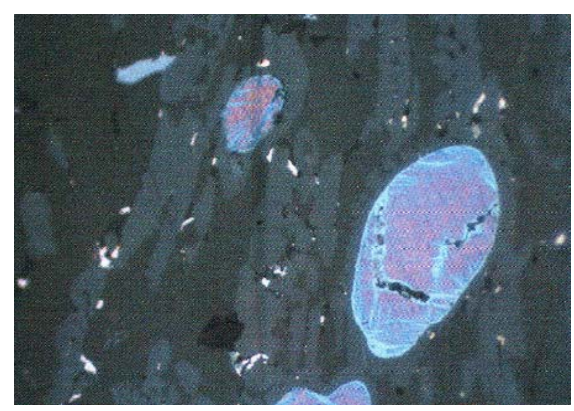

Fig. 5. Copper matte in fayalitic basis, lens 50X, II Nikoli

\section{TECHNICAL DESCRIPTION OF THE GRANULATION PROCESS IN THE LABORATORY CONDITIONS}

The term granulation includes the sudden cooling of liquid slag the pressure of cold water and slag obtaining in the form of irregular granules. The quality of granules depends on the chemical composition of slag, slag temperature prior to discharge, discharge rate of slag, pressure and quantity of cooling water.

For laboratory conditions, the slag, taken from the dump, was used in a piece form of various sizes.
Having collected such slag, exposed to the atmospheric, contains also the physical moisture, before its melting, it is necessary to dry it. The delivered slag was subjected to natural drying and spread over larger area in order to eliminate the physical moisture. Upon completion the natural drying, many samples are taken from different places and a composite sample is formed, which is sent for analysis. Chemical composition of a sample is shown in Table 3

Table 3. Chemical composition of a sample

\begin{tabular}{|c|c|c|c|c|c|c|c|c|}
\hline $\begin{array}{c}\text { Compounds - chemical } \\
\text { elements }\end{array}$ & $\mathbf{C u}$ & $\mathbf{F e}_{3} \mathbf{O}_{4}$ & $\mathbf{C a O}$ & $\mathbf{S}$ & $\mathbf{F e}$ & $\mathbf{F e O}$ & $\mathrm{SiO}_{2}$ & $\mathbf{A l}_{2} \mathbf{O}_{3}$ \\
\hline Content, \% & 0.68 & 1.754 & 17.26 & 1.07 & 25.69 & 26.75 & 43.76 & 3.89 \\
\hline
\end{tabular}

\section{Description of granulator}

Slag granulation is carried out in laboratory conditions, and a special device was used to make granules. Previously dried and analyzed slag was subjected to melting in the induction furnace for melting, $100 \mathrm{kWh}$ in a pot, volume $\mathrm{V}=10 \mathrm{l}$, the manufacturer ELING - Loznica. During experiment, $25 \mathrm{~kg}$ of slag was melted (chemical composition shown in Table 1), at temperature at which the slag was discharged $t=1250^{\circ} \mathrm{C}$. Measuring the temperature of slag was carried out using the immersion pyrometer.
The constructed special granulator is mobile and provides the sudden cooling of slag by jets, which are located on the front part of the tank, just behind the granulator drum, with a submerged part in cooling water. A carrying the basket is below a roller with perforated bottom, which accepts the resulting granules and that after discharge the entire amount of slag from the furnace is removed with a crane, and after filtering, stored in a basket for granulated slag. 
Such constructed granulator has $25 \mathrm{~kg}$ of granulated slag. Granulated slag com-

position is given in Table 4.

Table 4. Chemical composition of granulated slag

\begin{tabular}{|c|c|c|c|c|c|c|c|}
\hline $\begin{array}{c}\text { Compounds - chemical } \\
\text { elements }\end{array}$ & $\mathbf{C u}$ & $\mathbf{S}$ & $\mathbf{F e}$ & $\mathbf{S i O}_{\mathbf{2}}$ & $\mathbf{C a O}$ & $\mathbf{A l}_{\mathbf{2}} \mathbf{O}_{\mathbf{3}}$ & $\mathbf{F e}_{\mathbf{3}} \mathbf{O}_{\mathbf{4}}$ \\
\hline Content, \% & 0.33 & 0.20 & 27.92 & 46.72 & 19.60 & 4.52 & 3.41 \\
\hline
\end{tabular}

Difference in chemical composition before and after granulation of slag is explained by separation of special phase (copper matte - $\mathrm{Cu}_{2} \mathrm{~S} \mathrm{FeS}$ ) that was trapped in the pieces of slag.

After carried out manual separation, a small amount of copper matte was separated and given to a chemical analysis. The results of copper matte chemical analysis are given in Table 5 .

Table 5 Chemical composition of copper matte from granulated slag

\begin{tabular}{|c|c|c|}
\hline $\begin{array}{c}\text { Ele- } \\
\text { ments, \% }\end{array}$ & Slag & Analytical method \\
\hline $\mathbf{C u}$ & 17.04 & $\mathrm{EG}$ \\
\hline $\mathbf{F e}$ & 36.38 & $\mathrm{~V}$ \\
\hline $\mathbf{S}$ & 15.13 & $\mathrm{~S}$ \\
\hline $\mathbf{C a O}$ & 7.40 & $\mathrm{AAS}$ \\
\hline $\mathbf{F e O}$ & 44.02 & $\mathrm{R}$ \\
\hline $\mathbf{F e}_{\mathbf{3}} \mathbf{O}_{\mathbf{4}}$ & 6.53 & $\mathrm{~A}-\mathrm{Fe}_{3} \mathrm{O}_{4}$ \\
\hline $\mathrm{SiO}_{\mathbf{2}}$ & 17.00 & $\mathrm{G}$ \\
\hline $\mathbf{A l}_{\mathbf{2}} \mathbf{O}_{3}$ & 1.63 & $\mathrm{AAS}$ \\
\hline
\end{tabular}

$A A S$ - atomic absorption spectrophotometry,

$G$ - gravimetry,

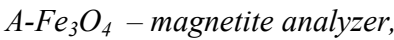

$V$-volumetry,

$E G$-, S-incineration, $R$ - computational

\section{CONCLUSION}

Based on chemical and mineralogical analyses, it can be concluded that two stages are separated in slag granulation:

- low-grade on copper (granulated slag) with $0.33 \% \mathrm{Cu}$, Table 4 ,

- high-grade on copper (copper matte) with $17.4 \% \mathrm{Cu}$, Table 5 .
In future work, the possibility of obtaining the copper matte will be considered using the physical methods of concentration. High copper content in copper matte gives the possibility of increasing the economic profit due to favorable copper price on domestic and the world market. Based on the physical-chemical characteristics of copper matte, the possibility of use the physical methods of concentration should be considered for their separation from the fayalitic basis as well as the possibility of experimental production for improving the technological results.

\section{REFERENCES}

[1] D. Kržanović, R. Rajković, V. Marinković, Geological Characteristics, Modeling and Technical Solution of Mining the Technogenetic Deposit "Slag Depot 1" in Bor, Mining Engineering 1(2009), pp. 7-17;

[2] S. Magdalinović, D. Milanović, B. Čađenović, V. Marjanović, Technological Method of Slag Granulation to Reduce the Grain-size at the Inlet of Flotation, Mining Engineering 3/2011, pp. 101-111;

[3] B. Čađenović. B. Drobnjaković. D. Milanović. S. Magdalinović. New Laboratory Plant for Franulation by the Changed technological Method of Pouring the Smelter Slag, Mining Engineering 4(2011), pp. 93-99.

[4] www.scribd.com/doc/39205125/ Minerali-i-Magmatske-Stene 